\title{
Isolation and Susceptibility to Antibiotics of Lactic Acid Bacteria from Fermented Beef Product (Mum)
}

\author{
P. Sornplang ${ }^{1}$ and V. Leelavatcharamas ${ }^{2}$ \\ 1. Department of Veterinary Public Health, Faculty of Veterinary Medicine, Khon Kaen University, Khon Kaen 40002, Thailand \\ 2. Fermentation Research Center for Value Added Agricultural Products, Faculty of Technology, Khon Kaen University, Khon Kaen \\ 40002, Thailand
}

Received: May 30, 2011 / Published: November 20, 2011.

\begin{abstract}
Important properties of beneficial microbes, e.g. lactic acid bacteria (LAB), characteristics and antimicrobial susceptibility of the microbes in fermented food products were concerned in several countries. The aim of this study was to determine the antimicrobial susceptibility of LAB strain isolated from Thai traditional fermented beef product, mum. The concentration of this LAB was also studied. Antimicrobial susceptibility and resistance of 14 representative LAB strains to 8 antibiotics were investigated using the disk diffusion method. The antibiotic used for the tests included Penicillin, Ampicillin, Erythromycin, Tetracycline, Vancomycin, Streptomycin, Sulfamethoxazole-trimethoprim and Metronidazole. The average concentration of LAB, of which the product was fermented at room temperature for 2 days, was $2.5 \times 10^{11} \mathrm{CFU} / \mathrm{g}$ of product. The inhibition zone diameters of all antibiotics were between $0 \mathrm{~mm}$ and $30 \mathrm{~mm}$ for all the LAB strains isolated and tested. All $14 \mathrm{LAB}$ isolates were resistant to Vancomycin, Streptomycin, Sulfamethoxazole-trimethoprim and Metronidazole. The LAB strains were highly resistant to Tetracycline (11 isolates), to Penicillin (10 isolates) but showed low resistant to Ampicillin (4 isolates). All of 14 LAB isolates were sensitive to Erythromycin. Only 3 LAB isolates were sensitive to all 4 antibiotics (Penicillin, Ampicillin, Erythromycin and Tetracycline), which were commonly used in the treatment of bacterial infections for human and animals. These 3 LAB isolates could possibly be used as starter cultures in this fermented product.
\end{abstract}

Key words: Antimicrobial susceptibility, lactic acid bacteria, fermented beef product, mum.

\section{Introduction}

Thai traditional fermented foods are produced by natural fermentation from various foods included fishery product (nam-pla, ka-pi, bu-du), fermented fish (pla-ra, pla-som, pla-chao, som-fak, pla-chom), meat products (nham, Sai-krog-prieo, mum) and plant products (naw-mai-dong, Phak-gard-dong, Miang, Khao-mak, khanom-jeen) [1]. Mum is found in the north eastern part of Thailand. It is produced from shredded pork or beef meat with ground roasted gelatinous rice (khaao khuaa), salt and garlic. Mum is fermented at room temperature for 2 days. In Thailand,

Corresponding author: P. Sornplang, Ph.D., research fields: lactic acid bacteria, probiotics, veterinary public health. E-mail: pirson@kku.ac.th. lactic acid bacteria (LAB) are a large group of beneficial bacteria that produce lactic acid as an end product of the food fermentation. Currently, there is concern about the possible spread of antibiotic resistant from antibiotics used for inhibition of pathogenic microorganisms or from beneficial microbes occurred naturally in foods. LAB from fermented products may act as a reservoir of antibiotic resistance genes that could be transferred to pathogenic bacteria or normal flora in the gastrointestinal tract of human and animals [2]. Antibiotic resistance of LAB are of two characteristics: (i) natural or intrinsic resistance, being nontransmissible; (ii) acquired resistance, usually caused from bacterial mutation or may carry plasmid encoding of antibiotic resistance genes and potentially 
transmissible to other bacteria [3]. There is little information about the antibiotic susceptibility in commensally bacteria such as LAB isolated from fermented food products and no data exist about antibiotic susceptibility in LAB of fermented beef products, mum. The present studies were to isolate the $\mathrm{LAB}$ and to investigate their antibiotic susceptibility profiles isolated from the mum products.

\section{Materials and Methods}

\subsection{Sample Collection and Isolation of Lactic Acid Bacteria (LAB)}

In June 2010, twenty samples of fermented beef products, mum have been collected from local markets (along the road) in the area of Aumphur Pol, Khon Kaen Province. Mum was made from beef meat. Ten kilograms of shredded meat were grinded and then garlic, salts and ground gelatinous rice were added. It was fermented at room temperature for 2 days. Ingredient proportions of the mum product are shown in Table 1. Samples were kept in air-tight plastic bags and were also kept at $4{ }^{\circ} \mathrm{C}$. To find the volume of lactic acid bacteria, the samples were divided into portions of 5 grams that were dissolved into 45 milliliters of solvent Maximum Recovery Diluents (MRD) (Oxoid Inc., Hampshire, UK) and agitated for $30 \mathrm{~s}$. Serial 10 -fold dilutions from the homogenate were made according to ISO-6887-1 [4] and plated in De Man Rogosa and Sharpe (MRS) agar [5] with modification by added $0.4 \%(\mathrm{w} / \mathrm{v}) \mathrm{CaCO}_{3}$ using the pour plate method. The incubation was carried out aerobically for $2 \mathrm{~d}$ at $37^{\circ} \mathrm{C}$ as described by ISO-15214 [6]. Bacterial colonies were enumerated by produced acid which clear zone surrounding from the plate that grew 30-300 colonies. Bacterial concentrations calculated (volume

Table 1 Ingredients used in mum processing.

\begin{tabular}{ll}
\hline Ingredients & Total weight \\
\hline Beef minced & 10 kilograms \\
Garlic & 1 kilogram \\
Salts & 100 grams \\
Ground roasted gelatinous rice & 100 grams \\
\hline
\end{tabular}

of bacterial colonies $\times$ dilution factor) and expressed as colony forming unit per gram of sample (CFU/g). The different morphologies of bacterial colonies from each sample were picked up and stored in a modified freezing medium (Trypticase Soy Broth (Criterion ${ }^{\mathrm{TM}}$ ), $0.6 \%$ yeast extract and $20 \%$ glycerol) at $-70{ }^{\circ} \mathrm{C}$ for further test.

Cell morphologies of bacteria were checked using Gram staining. The isolates were tested a catalase reaction. Rod and coccal cells of bacteria showed catalase negative and gram positive were characterized as LAB [7] and they were selected for further test.

\subsection{Antimicrobial Susceptibility Test}

The representative $\mathrm{LAB}$ isolates were further tested for antimicrobial susceptibility by the disk diffusion method [8]. Eight antibiotics commonly used in treating human or animal infections [9] and provided different antibiotics classes were chosen for the test. They were penicillin $\mathrm{G}(10 \mu \mathrm{g})$, ampicillin $(10 \mu \mathrm{g})$, erythromycin $(15 \mu \mathrm{g})$, tetracycline $(30 \mu \mathrm{g})$, vancomycin (30 $\mu \mathrm{g})$, streptomycin $(10 \mu \mathrm{g})$, sulfamethoxazole-trimethoprim $\quad(25 \mu \mathrm{g})$ and metronidazole $(50 \mu \mathrm{g})$. All antibiotic disks (diameter $=6 \mathrm{~mm}$ ) were obtained from Oxoid (Oxoid, England).

The antimicrobial susceptibility test was similar to those as described in Ref. [10]. Briefly, each LAB isolate was inoculated with $10^{8} \mathrm{CFU}$ (turbidity of 0.5 Mac Farland standards) at $37^{\circ} \mathrm{C}$ in MRS broth and incubated anaerobically for $18 \mathrm{~h}$. Culture solution was dipped using sterile cotton swap and swabbed in three directions on Mueller-Hinton agar plates. All antibiotic disks were seeded in the plates and incubated anaerobically at $37{ }^{\circ} \mathrm{C}$ for $48 \mathrm{~h}$. The diameters of antibiotic inhibition zones were measured using a ruler under a colony counter apparatus (Gallenkamp, England) and expressed in millimeters which included diameter of antibiotic disk. Antimicrobial susceptibility interpreted according to the cut-off levels proposed in Ref. [10] with strains considered resistant if inhibition zone diameters were 
equal to or smaller than $19 \mathrm{~mm}$ for penicillin $\mathrm{G}$ and ampicillin, $14 \mathrm{~mm}$ for vancomycin and tetracycline, and $13 \mathrm{~mm}$ for erythromycin. Equal to or smaller than $8 \mathrm{~mm}$ of inhibition zone diameters for streptomycin, sulfamethoxazole-trimethoprim and metronidazole were considered as resistant, according to the cut-off levels with minimal modifications of Ref. [11]. All antibiotics were tested in duplicate.

\section{Results and Discussion}

\subsection{Lactic Acid Bacteria Isolation}

Lactic acid bacteria were successfully isolated from the fermented beef products, mum using a selective medium of MRS agar and modification by the added $0.4 \%(\mathrm{w} / \mathrm{v}) \mathrm{CaCO}_{3}$. They showed clear zone appearance surrounding bacterial colonies. These clear zone colonies were because of the reaction of acid production from them. However, these colonies were confirmed as LAB using cell morphologies, Gram staining and catalase reaction. There were researchers who had attempted to develop the selective medium for lactobacilli [12]. In this study, the selective medium (MRS agar) was developed easily to isolate the LAB. Characteristics of 20 bacteria isolates and concentration of 14 representative LAB strains are shown in Table 2 and Table 3, respectively.

\subsection{Antimicrobial Susceptibility}

Results of antimicrobial susceptibility are shown in Table 4. All LAB isolates in this study showed resistance to vancomycin, sulfamethoxazole-trimethoprim, metronidazole and aminoglycoside antibiotics (streptomycin). These LAB strains presented intrinsic mechanisms of resistance for these antibiotics. All LAB strains in this study were resistant to metronidazole as similar report of Ref. [2]. This antibiotic resistance was usually intrinsic character. Although LAB strains are speciesdependent intrinsic resistance to sulfamethoxazole-trimethoprim [13], all LAB strains
Table 2 Characteristics of 20 bacteria isolates isolated from the fermented beef products, mum.

\begin{tabular}{llll}
\hline $\begin{array}{l}\text { Bacteria } \\
\text { isolates }\end{array}$ & Cell form & Gram straining & Catalase \\
\hline M1 & Rods & + & - \\
M2 & Rods & + & - \\
M3 & Rods & + & - \\
M4 & Rods & + & - \\
M5 & Rods & + & - \\
M6 & Rods & + & - \\
M7 & Rods & + & - \\
M8* & Rods & - & - \\
M9 & Rods & + & - \\
M10* & Rods & + & + \\
M11 & Rods & + & - \\
M12 & Rods & + & - \\
M13* & Cocci & + & + \\
M14 & Rods & + & - \\
M15* & Rods & - & - \\
M16* & Rods & + & + \\
M17 & Rods & + & - \\
M18 & Rods & + & - \\
M19 & Rods & + & - \\
M20* & Cocci & + & Isolates were \\
\hline +: Positive & reaction; & Negative reaction; \\
excluded from the basic properties of LAB. &
\end{tabular}

Table 3 Concentration of 14 representative LAB strains isolated from the fermented beef product, mum.

\begin{tabular}{|c|c|c|c|}
\hline $\begin{array}{l}\text { Number } \\
\text { of sample }\end{array}$ & $\begin{array}{c}\text { Average numb } \\
\text { various }\end{array}$ & $\begin{array}{l}\text { ff colony }{ }^{1} \text { at } \\
\text { tions }\end{array}$ & $\begin{array}{l}\text { Average LAB } \\
\text { count (CFU/g) }\end{array}$ \\
\hline & $10^{-8} \quad 10^{-9}$ & $10^{-10}$ & \\
\hline 14 & $n c^{2}$ & 25 & $2.5 \times 10^{11}$ \\
\hline
\end{tabular}

in our study showed intrinsic resistance to sulfamethoxazole-trimethoprim which they may have some antagonistic components such as p-aminobenzoic acid and thymidine [14]. All LAB strains in this study showed intrinsic resistance to vancomycin, these strains were due to the presence of D-alanine ligase and this enzyme could be inactivated vancomycin activity [15]. Acquired antibiotic resistances in some LAB strains in this study showed resistant to penicillin, ampicillin and tetracycline. These strains may receive the antibiotic resistance that spread out in bacteria from bacterial treatments of animal infections. This study showed low resistance to 
Table 4 Interpretative zone diameter $(\mathrm{mm})$ with eight antibiotics of 14 representatives LAB strains selected from fermented beef product, mum.

\begin{tabular}{|c|c|c|c|c|c|c|c|c|}
\hline \multirow{2}{*}{$\begin{array}{l}\text { Bacteria } \\
\text { strains }\end{array}$} & \multicolumn{8}{|c|}{ Antibiotics } \\
\hline & $\mathrm{P}(10 \mu \mathrm{g})$ & AMP $(10 \mu \mathrm{g})$ & $\mathrm{E}(15 \mu \mathrm{g})$ & TE $(30 \mu \mathrm{g})$ & VA $(30 \mu \mathrm{g})$ & $\mathrm{S}(10 \mu \mathrm{g})$ & $\mathrm{SXT}(25 \mu \mathrm{g})$ & MTZ $(50 \mu \mathrm{g})$ \\
\hline M1 & $17.5(\mathrm{R})$ & 21 (MS) & $23(S)$ & $13(\mathrm{R})$ & $0(\mathrm{R})$ & $7(\mathrm{R})$ & $0(\mathrm{R})$ & $0(\mathrm{R})$ \\
\hline M2 & $17(\mathrm{R})$ & $17(\mathrm{R})$ & $23(\mathrm{~S})$ & $12(\mathrm{R})$ & $0(\mathrm{R})$ & $0(\mathrm{R})$ & $0(\mathrm{R})$ & $0(\mathrm{R})$ \\
\hline M3 & $30(\mathrm{~S})$ & $30(\mathrm{~S})$ & $26(S)$ & $17(\mathrm{~S})$ & $0(\mathrm{R})$ & $0(\mathrm{R})$ & $0(\mathrm{R})$ & $0(\mathrm{R})$ \\
\hline M4 & $22(S)$ & $17(\mathrm{R})$ & $25(S)$ & $8(\mathrm{R})$ & $0(\mathrm{R})$ & $0(\mathrm{R})$ & $0(\mathrm{R})$ & $0(\mathrm{R})$ \\
\hline M5 & $17(\mathrm{R})$ & $28(S)$ & $24(S)$ & $14(\mathrm{R})$ & $0(\mathrm{R})$ & $0(\mathrm{R})$ & $0(\mathrm{R})$ & $0(\mathrm{R})$ \\
\hline M6 & $17.5(\mathrm{R})$ & 20 (MS) & $25.5(\mathrm{~S})$ & $8(\mathrm{R})$ & $0(\mathrm{R})$ & $8(\mathrm{R})$ & $0(\mathrm{R})$ & $0(\mathrm{R})$ \\
\hline M7 & $28(S)$ & $28(S)$ & $25(S)$ & $18(\mathrm{~S})$ & $0(\mathrm{R})$ & $0(\mathrm{R})$ & $0(\mathrm{R})$ & $0(\mathrm{R})$ \\
\hline M9 & $17(\mathrm{R})$ & $28(S)$ & $23(S)$ & $14(\mathrm{R})$ & $0(\mathrm{R})$ & $0(\mathrm{R})$ & $0(\mathrm{R})$ & $0(\mathrm{R})$ \\
\hline M11 & $18(\mathrm{R})$ & $17(\mathrm{R})$ & $23(S)$ & $13(\mathrm{R})$ & $0(\mathrm{R})$ & $8(\mathrm{R})$ & $0(\mathrm{R})$ & $0(\mathrm{R})$ \\
\hline M12 & $29(S)$ & 29 (S) & $26(S)$ & $17(\mathrm{~S})$ & $0(\mathrm{R})$ & $0(\mathrm{R})$ & $0(\mathrm{R})$ & $0(\mathrm{R})$ \\
\hline M14 & $18(\mathrm{R})$ & $16(\mathrm{R})$ & $23(S)$ & $13(\mathrm{R})$ & $9(\mathrm{R})$ & $8(\mathrm{R})$ & $0(\mathrm{R})$ & $0(\mathrm{R})$ \\
\hline M17 & $17.5(\mathrm{R})$ & 21 (MS) & $23(S)$ & $14(\mathrm{R})$ & $8(\mathrm{R})$ & $7(\mathrm{R})$ & $0(\mathrm{R})$ & $0(\mathrm{R})$ \\
\hline M18 & $19(\mathrm{R})$ & 23 (MS) & $24(S)$ & $14(\mathrm{R})$ & $8(\mathrm{R})$ & 7 (R) & $0(\mathrm{R})$ & $0(\mathrm{R})$ \\
\hline M19 & 19 (R) & 24 (MS) & $24(S)$ & $14(\mathrm{R})$ & $9(\mathrm{R})$ & $8(\mathrm{R})$ & $0(\mathrm{R})$ & $0(\mathrm{R})$ \\
\hline
\end{tabular}

Susceptibility expressed as (R), resistant; (MS), moderately susceptible; (S), sensitive; susceptible.

$\mathrm{P}=$ penicillin; $\mathrm{AMP}=$ ampicillin; $\mathrm{E}$ = erythromycin; $\mathrm{TE}$ = tetracycline; $\mathrm{VA}$ = vancomycin;

$\mathrm{S}=$ streptomycin; SXT = sulfamethoxazole-trimethoprim; MTZ = metronidazole.

penicillin (71.43\%) than the study of Savadogo et al. [16] who reported that LAB strains isolated from Faso fermented milk showed $78.94 \%$ of penicillin resistances. Lactobacillus spp. isolated from chicken feces has been reported at $36.37 \%$ of tetracycline resistances [17]. In this study, LAB isolated from mum showed highly resistant to tetracycline (78.57\%). The selected 3 LAB isolates (M3, M7, M12) were intrinsic resistance to vancomycin, sulfamethoxazole-trimethoprim, metronidazole and streptomycin but they were sensitive to all 4 antibiotics (Penicillin, Ampicillin, Erythromycin and Tetracycline), which were commonly used in the treatment of bacterial-infections for human and animals. Therefore, these $3 \mathrm{LAB}$ isolates could be safely applied and could possibly be used as starter cultures in this fermented product.

\section{Conclusion}

Although lactic acid bacteria are a large group of bacteria isolated from traditional fermented beef product (mum) in Thailand, there are only some strains that are sensitive to antibiotics commonly used in animals. The selection of these bacterial strains used for the starter culture in food fermentation is an alternative that will give consumers confidence and not to eat products containing lactic acid bacteria to be the reservoirs transferred an antibiotic resistance genes to other bacteria. Further research, should be tested for sensitivity to the antibiotics in the other traditional Thai fermented foods that from animal origins including pla-som, pla-chom and nham.

\section{Acknowledgments}

The authors would like to thank the Department of Veterinary Public Health, Faculty of Veterinary Medicine, Khon Kaen University, Thailand for bacterial laboratory facility and also would like to thank Associate Professor Kriengsak Poonsuk for valuable advice on lactic acid bacteria isolation techniques.

\section{References}

[1] S. Tanasupawat, Thai lactic acid bacteria: diversity and applications, Srinakharinwirot Sci. J. 25 (2009) 1-13.

[2] A.B. Florez, S. Delgado, B. Mayo, Antimicrobial susceptibility of lactic acid bacteria isolated from a 


\section{Isolation and Susceptibility to Antibiotics of Lactic Acid Bacteria from Fermented Beef Product (Mum)}

cheese environment, Can. J. Microbiol. 51 (2005) 51-58.

[3] P. Courvalin, Antibiotic resistance: the pros and cons of probiotics, Dig. Liver Dis. 38 (2006) 261-265.

[4] ISO-6887-1, Microbiology of Food Animal Breeding Stuffs - Preparation of Test Samples, Initial Suspension and Decimal Dilution for Microbiological Examination, Part 1: General Rules for the Preparation of the Initial Suspension and Decimal Dilution, 1999.

[5] J.C. De Man, M. Rogosa, E.M. Sharpe, A medium for the cultivation of lactobacilli, J. Appl. Bacteriol. 23 (1960) 30-35.

[6] ISO-15214, Microbiology of Food Animal Breeding Stuffs-Horizontal Method for the Enumeration of Mesophilic Lactic Acid Bacteria-Colony-Count Technique, 1998.

[7] S. Salminen, A. von Wright, A. Ouwehand, Lactic Acid Bacteria: Microbiological and Functional Aspects, Marcel Dekker, Inc., New York, 2004, p. 633.

[8] A. Bauer, W.M. Kirby, J.C. Sherris, M. Turck, Antibiotic susceptibility testing by a standardized single disk method, Am. J. Clin. Pathol. 45 (1966) 493-496.

[9] European Food Safety Authority, Scientific opinion of the panel on biological hazards on a request from the European Food Safety Authority on food borne antimicrobial resistance as a biological hazard, The EFSA Journal 765 (2008) 1-87.

[10] W.P. Charteris, P.M. Kelly, L. Morelli, J.K. Collins, Antibiotic susceptibility of potentially probiotic Lactobacillus species, J. Food Prot. 61 (1981) 636-1643.

[11] K.B.P.K. Reddy, P. Raghavendra, B.G. Kumar, M.C.
Misra, S.G. Prapulla, Screening of probiotic properties of lactic acid bacteria isolated from Kanjika, an ayruvedic lactic acid fermented product: an in vitro evaluation, J. Gen. Appl. Microbiol. 53 (2007) 207-213.

[12] M.S. Jackson, A.R. Bird, A.L. McOrist, Comparison of two selective media for the detection and enumeration of lactobacilli in human faces, J. Microbiol. Methods. 51 (2002) 313-321.

[13] I. Klare, C. Konstabel, G. Werner, G. Huys, V. Vankerckhoven, G. Kahlmeter, et al., Antimicrobial susceptibilities of Lactobacillus, Pediococcus and Lactococcus human isolates and cultures intended for probiotic or nutritional use, J. Antimicrob. Chemother. 59 (2007) 900-912.

[14] J.D. Turnidge, J.M. Bell, Antimicrobial susceptibility on solid media, in: V. Lorian (Ed.), Antibiotics in Laboratory Medicine, Williams \& Wilkins, Baltimore, 2005, pp. 8-60.

[15] B.G. Elisha, P. Courvalin, Analysis of genes encoding D-alanine: D-alanine ligase-related enzymes in Leuconostoc mesenteroides and Lactobacillus spp., Gene 152 (1995) 79-83.

[16] A. Savadogo, C.A.T. Ouattara, A.J. Ilboudo, D. Karou, A.S. Traore, Isolation and susceptibility to antibiotics of bacterial strains from Burkina Faso fermented milk samples, Advance J. Food Sci. Technol. 2 (2010) 91-95.

[17] P. Sornplang, V. Leelavatcharamas, Antimicrobial susceptibility of probiotic lactobacilli isolated from chicken feces, Khon Kaen Univ. Res. J. 15 (2010) 689-697. 